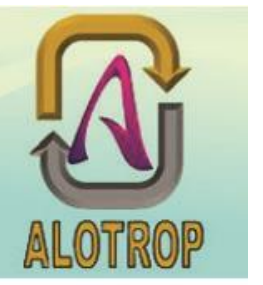

\title{
PERBANDINGAN HASIL DAN MINAT BELAJAR KIMIA SISWA KELAS X IPA MENGGUNAKAN MODEL PEMBELAJARAN KOOPERATIF SNOWBALL THROWING DAN TALKING STICK PADA KURIKULUM-2013 DI SMAN 10 KOTABENGKULU
}

\author{
RikaJuwita Saputri ${ }^{*}{ }^{1}$, Sumpono $^{2}$, RinaElvia $^{3}$ \\ ${ }^{1,2,3}$ Program Studi Pendidikan Kimia Jurusan PMIPA FKIP \\ Universitas Bengkulu \\ ${ }^{1}$ E-mail : rikajuwitasaputri@gmail.com
}
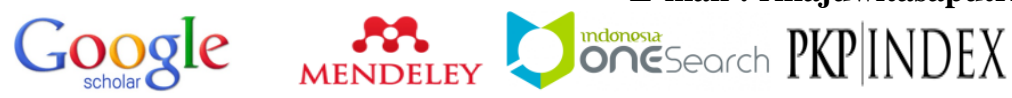

Academia.edu

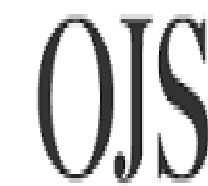

Open ound ytems

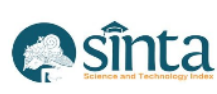

\begin{abstract}
The purpose of this research to determine the difference in learning outcome and interest of students on chemistry learning between class which applied snowball throwing and class which applied talking stick learning model on nomenclatur of chemical compounds material in curriculum-2013 of grade X IPA in SMA Negeri 10 Bengkulu City. Research conducted is a research with the type of quasi experiment. Analysis of the data used are mean values, normality test, homogeneity test, and t-test. Chemistry learning outcome data obtained pretest and posttest value where average improvement value of cognitive learning result for snowball throwing class and talking stick class are 56,970 and 45,606. While the interest of students learning of both experiment classes procure percentage are $81,567 \%$ and $75,373 \%$. The result of t test with significant level $(\alpha=0,05)$, then got value for tcount >ttable is 4,734 > 1,669 for learning result and 3,596 > 1,669 for interest learning. The results showed that there were significant differences in learning outcomes and learning interest between classes that applied snowball throwing learning and classes that applied the talking stick learning model.
\end{abstract}

Keywords: Learning Interest, Learning Outcome, Snowball Throwing, Talking Stick

\section{ABSTRAK}

Tujuan dari penelitian ini untuk menentukan perbedaan hasil dan minat belajar kimia siswa antara kelas yang menerapkan model pembelajaran snowball throwing dengan kelas yang menerapkan model pembelajaran talking stick pada materi tatanama senyawa kimia dalam kurikulum-2013 di kelas X IPA SMA Negeri 10 Kota Bengkulu tahun ajaran 2017-2018. Penelitian yang dilakukan merupakan penelitian dengan jenis eksperimen semu. Populasi penelitian berjumlah 3 kelas X IPA dengan sampel 2 kelas X IPA yg homogen sebagai kelas eksperimen I dan II dengan jumlah total siswa 66 orang.Analisis data yang digunakan adalah nilai rata-rata (mean), uji normalitas, uji homogenitas, dan uji hipotesis menggunakan uji t. Data hasil belajar kimia siswa diperoleh dari nilai pretest dan nilai postest dimana nilai rata-rata peningkatan hasil belajar kognitif untuk kelas snowball throwing dan kelas talking stick adalah 56,970 dan 45,606. Sedangkan minat belajar kimia siswa pada kedua kelas memperoleh persentase sebesar 81,567\% dan 75,373\%. Hasil uji t dengan taraf signifikan $5 \%(\alpha=0,05)$, maka didapatkan nilai untuk thitung > ttabel yaitu 4,734 > 1,669 untuk hasil belajar dan 3,596 > 1,669 untuk minat belajar. Hasil penelitian menunjukkan bahwa terdapat perbedaan hasil dan minat belajar yang signifikan antara kelas X IPA di SMAN 10 Kota Bengkulu tahun ajaran 2017-2018 untuk kelas yang menerapkan model pembelajaran snowball throwing dengan kelas yang menerapkan model pembelajaran talking stick pada materi tata nama senyawa kimia.

Kata Kunci: Hasil Belajar, Minat Belajar, Snowball Throwing, Talking Stick

\section{PENDAHULUAN}

Pendidikan memegang peranan penting dalam menciptakan masyarakat yang cerdas, damai,terbuka,dan demokratis [1], dimana rendahnya mutu pendidikan merupakan masalah utama dari dunia pendidikan yang akan mempengaruhi harkat dan martabat bangsa Indonesia [2]. Rendahnya mutu pendidikan dapat disebabkan proses pembelajaran yang belum efektif [3], karena itu seorang guru harus memperhatikan strategi belajar mengajar, sehingga tercipta situasi yang efektif dan efisien sesuai dengan pokok bahasan materi pelajaran yang akan diajarkan [4].Berbagai macam cara telah dilakukan untuk meningkatkan mutu pendidikan disekolah, diantaranya dengan perbaikan mutu pembelajaran [5]. Pada proses pembelajaran disekolah perencanaan pembelajaran yang baik akan mendukung keberhasilan dalam pembelajaran [6], dengan salah satunya adalah didalam memilih model pembelajaran yang akan digunakan [7]. Model pembelajaran ialah pola yang digunakan sebagai pedoman dalam merencanakan pembelajaran dikelas maupun tutorial [8]. Suatu model pembelajaran dapat dijadikan pola pilihan, artinya para guru boleh memilih model pembelajaran yang sesuai dan efektif untuk mencapai tujuan pembelajaran [9], 
sehingga diharapkan terjadinya perubahan yang bagus terhadap hasil belajar siswa [10].

Salah satu faktor ekternal yang mempengaruhi prestasi belajar adalah pendekatan pembelajaran [11]. Berdasarkan kurikulum yang berlaku saat ini yaitu Kurikulum 2013 menghendaki para peserta didik untuk mempelajari suatu prinsip dan konsep materi melalui pendekatan saintifik [12]. Dalam hal ini, pendekatan saintifik merupakan pendekatan pembelajaran yang berpusat pada peserta didik, dengan langkah-langkah seperti mengamati, menanya, mengumpulkan informasi mengasosiasiakan, dan mengkomunikasikan [13]. Hasil akhirnya adalah peningkatan kemampuan dari peserta didik yang meliputi aspek kompetensi kognitif (pengetahuan), afektif (sikap), dan psikomotorik (keterampilan) [14].

Berdasarkan hasil wawancara dengan salah satu guru mata pelajaran kimia di SMAN 10 Kota Bengkulu didapatkan bahwa rata-rata hasil ujian akhir semester 1 mata pelajaran kimia kelas X IPA masih banyak dibawah KKM yaitu 72. Adapun daftar nilai rata-rata ujian akhir semester ganjil siswakelasX berturut-turut dari X IPA 1, XIPA 2, X IPA 3 yaitu 64,242; 63,424; dan 65,265. Hal ini diduga bahwa siswa masih sulit memahami materi yang disampaikan, terkhususnya dalam hal konsep dari materi.Kurangnya minat belajar siswa terhadap mata pelajaran kimia serta materi yang cukup sulit bagi siswa juga dapat berpengaruh pada hasil belajar. Ini dapat diketahui dari respon siswa yang masih rendah terhadap pertanyaan dan penjelasan guru serta siswa masih terlihat pasif saatproses pembelajaran.Untuk membangkitkan minat belajar pada siswa dapatdigunakan berbagai cara,salah satunya yaitu penggunaan model pembelajaran yang bervariasi. Pilihan model pembelajaran yang bervariasi banyak sekali, maka dapat dipilih model pembelajaran yang terdapat unsur permainan. Model pembelajaran yang dapat digunakan adalah Snowball Throwing dan Talking Stick.

Model pembelajaran snowball throwing adalah model pembelajaran dengan membentuk kelompok yang diwakili ketua kelompok untuk mendapat tugas dari guru kemudian masingmasing kelompok membuat pertanyaan yang ditulis dalam lembar kertas kerja yang dibentuk seperti bola lalu dilempar ke kelompok lain dan masing-masing kelompok menjawab pertanyaan dari bola yang diperoleh [15].
Selain Snowball Throwing, didalam pembelajaran kooperatif terdapat jenis model Talking Stick yaitu suatu model pembelajaran dengan bantuan tongkat dimana peserta didik yang memegang tongkat terlebih dahulu harus menjawab pertanyaan yang diajukan, demikian seterusnya [16].

Dengan penggunaan dua model pembelajaran kooperatif tersebut peneliti mengharapkan proses pembelajaran menjadi lebih menarik dan menyenangkan [17], sehingga dapat dilihat mana model pembelajaran yanglebih efektif dalam membantu peningkatan hasil dan minat belajar siswa pada pokok bahasan tata nama senyawa kimia..

Berdasarkan latar belakang yang telah diuraikan diatas maka peneliti bermaksud untuk melakukan penelitian dengan tujuan untuk menentukan perbedaan hasil dan minat belajar kimia siswa yang menerapkan model pembelajaran snowball throwing dan model pembelajaran talking stick pada kurikulum-2013.

\section{METODE PENELITIAN}

Penelitian ini menggunakan jenis penelitian semu eksperimen. Penelitian eksperimen semu menggunakan suatu percobaan yang dirancang secara khusus guna membangkitkan data yang diperlukan untuk menjawab pertanyaan penelitian [18].

Populasi dalam penelitianini adalah siswa kelas X IPA SMA Negeri 10 Kota Bengkulu tahun pelajaran 2017/2018 yang berjumlah 3 kelas. Pengambilan sampel dilakukan secara random sampling yang sebelumnya telah dilakukan uji homogenitas terhadap populasi.

Sampel yang terpilih adalah siswa kelas $\mathrm{X}$ IPA 1 sebagai kelas eksperimen I yang diberi perlakuan model Snowball Throwing dan X IPA 2 sebagai kelas eksperimen II diberi perlakuan model Talking Stick.

Variabel yang digunakan dalam penelitian ini yaitu variabel bebas dan variabe terikat. Variabel bebas yaitu model pembelajaran Snowball Throwing dan model pembelajaran Talking Stick. Variabel terikat yaitu hasil belajar kimia siswa dan minat belajar kimia siswa pada pokok bahasan tata nama senyawa kimia.

Teknik pengumpulan data dilakukan dengan menggunakan instrumen tes 10 pilihan ganda untuk mengukur prestasi belajar aspek 
kognitif dan instrumen nontes berupa kuesioner untuk mengetahui minat belajar siswa. Teknik analisis data terdiri atas uji prasyaratan analisis dan uji hipotesis. Uji prasyaratan analisis meliputi nilai rata-rata (mean), uji normalitas dan homogenitas, serta uji hipotesis yang menggunakan uji-t.

\section{HASIL DAN PEMBAHASAN}

Penelitian ini dilaksanakan pada bulan Januari-Februari 2018, di SMAN 10 Kota Bengkulu pada kelas X IPA1 dengan jumlah siswa sebanyak 33 siswa sebagai kelas eksperimen 1 dengan menggunakan model pembelajaran snowball throwing dan kelas X IPA 2 dengan jumlah siswa sebanyak 33 siswa sebagai kelas eksperimen 2 dengan menggunakan model pembelajaran talking stick. Kedua kelas ini dipilih berdasarkan uji normalitas dan homogenitasnya, sehingga sampel dapat ditentukan dengan cara random sampling sebanyak 2 kelas. Pada penelitian ini, untuk menentukan hasil belajar siswa digunakan tes yaitu pretest dan postest sedangkan minat belajar siswa pengambilan datanya menggunakan kuesioner.

Penelitian ini dilakukan sesuai dengan kurikulum yang berlaku pada saat ini yaitu Kurikulum-2013. Penerapan dari Kurikulum2013 menekankan pada siswa aktif yang menggunakan pendekatan saintifik dengan tahapan pembelajaran yaitu mengamati, menanya, mengumpulkan data, mengasosiasi, dan mengkomunikasikan [19]. Akan tetapi pada penelitian ini tahapan proses pembelajarannya dikemas dalam penerapan model pembelajaran snowball throwing dan talking stick sehingga hasil dan minat belajar yang akan didapatkan merupakan adanya pengaruh dari pendekatan saintifik. Karena kedua model pembelajaran tersebut terdapat unsur permainannya sehingga proses pembelajaran menjadi menyenangkan.

Hal ini juga didukung oleh penelitian sebelumnya yang menyatakan bahwa pembelajaran menyenangkan adalah proses pembelajaran yang harus berlangsung dalam suasana yang menyenangkan dan mengesankan sehingga akan menarik minat peserta didik untuk terlibat secara aktif, dan tujuan pembelajaran akan tercapai secara maksimal [20].

\section{Uji Validitas Kuesioner Minat Belajar Siswa}

Minat belajar siswa dapat diketahui dengan menggunakan data nontes berupa kuesioner. Sebelum kuesioner digunakan pada kedua kelas sampel penelitian, kuesioner tersebut dilakukan uji validitas. Uji validitas merupakan ukuran yang menunjukkan kevalidan dari setiap pernyataan yang tersedia [21]. Uji validitas dilakukan pada siswa yang bukan menjadi sampel penelitian dalam hal ini kelas yang digunakan yaitu kelas $\mathrm{X}$ IPA 3 yang berjumlah 34 siswa.

Data yang diperoleh dari skor-skor pernyataan dihitung dengan menggunakan program aplikasi SPSS 16 untuk mengetahui apakah setiap pernyataan dinyatakan valid atau tidak valid. Dasar pengambilan keputusan yaitudinyatakan valid jika nilai $r_{\text {hitung }} \geq r_{\text {tabel }}$ pada nilai $\alpha=5 \%$.

Dari hasil perhitungan validitas kuesioner didapatkan bahwa kuesioner minat belajar siswa yang awalnya berjumlah 50 butir pernyataan berkurang menjadi 41 butir pernyataan yang dinyatakan valid. Hal ini berarti terdapat 9 butir pernyataan yang dinyatakan tidak valid atau nilai dari $\mathrm{r}$ hitung $\leq \mathrm{r}$ tabel [22].

\section{Hasil Belajar Kelas Snowball Throwing dan TalkingStick}

Setelah dilakukan pretest dan postest, maka diperoleh data hasil belajar siswa pada tabel 1.

\begin{tabular}{|l|l|l|}
\hline \multirow{2}{*}{ Variabel } & \multicolumn{2}{|c|}{ Nilai } \\
\cline { 2 - 3 } & $\begin{array}{l}\text { Snowball } \\
\text { Throwing }\end{array}$ & $\begin{array}{l}\text { Talking } \\
\text { Stick }\end{array}$ \\
\hline Jumlah Siswa & 33 & 33 \\
\hline Pretest pertemuan 1 & 23,636 & 26,364 \\
\hline Pretest pertemuan 2 & 22,121 & 37,273 \\
\hline Postest pertemuan 1 & 78,485 & 73,939 \\
\hline Postest pertemuan 2 & 81,212 & 80,909 \\
\hline Rata-rata Pretest & 22,879 & 31,818 \\
\hline Rata-rata Postest & 79,848 & 77,424 \\
\hline Selisih nilai rata-rata $(\Delta i)$ & 56,970 & 45,606 \\
\hline
\end{tabular}

Tabel.1. Data Nilai Rata-rata Siswa

Berdasarkan data pada tabel 1, dapat diketahui bahwa nilai rata-rata pretest siswa baik pada pertemuan 1 dan pertemuan 2 masih 
tergolong rendah atau masih jauh dibawah standar nilai KKM yaitu 72. Sedangkan nilai rata-rata postest siswa sudah diatas standar nilai KKM. Selain itu juga dapat diketahui bahwa kelas eksperimen 1 mengalami peningkatan hasil belajar setelah diberi perlakuan penerapan model pembelajaran snowball throwing.

Rendahnya perolehan nilai pretest siswa menunjukkan bahwa pengetahuan materi awal siswa baik pada kelas eksperimen 1 maupun kelas eksperimen 2 masih sangat kurang karena tidak adanya kesiapan siswa sebelum pembelajaran dimulai sehingga tidak mampu mengerjakan soal pretest dengan baik. Hal ini siswa tidak paham dengan soal-soal pretest tentang materi yang akan dipelajari, sehingga siswa cenderung mengerjakan soal pretest dengan seadanya saja.

Pada proses pembelajaran kelas eksperimen 1 yang menggunakan model pembelajaran snowball throwing, setelah guru menyampaikan sedikit materi pembuka, siswa secara berkelompok memahami materi tata nama senyawa kimia dengan bantuan lembar LDPD dan menjawab latihan soal yang ada pada lembar LDPD tersebut. Pada tahapan awal inilah model pembelajaran snowball throwing dimodifikasi. Setelah itu siswa secara berkelompok membuat soal pada selembar kertas, kemudian kertas tersebut dibentuk seperti bola dan dilemparkan dari satu kelompok ke kelompok lainnya.

Kelompok yang mendapatkan bola harus menjawab pertanyaan yang tertulis pada kertas secara bergantian. Setelah selesai kemudian guru bersama siswa memberikan kesimpulan tentang materi tersebut.

Proses pemberian materi pada kelas eksperimen 2 dengan menerapkan model pembelajaran talking stick yaitu setelah siswa memahami materi dengan mengerjakan LDPD, kemudian siswa yang memegang tongkat akan menjawab pertanyaan yang diberikan guru setelah mempelajari materi pokoknya.

Dari data yang telah diuraikan tersebut maka dapat dilihat bahwa kelas eksperimen 1 dengan model pembelajaran snowball throwing memiliki nilai rata-rata postest yang lebih tinggi dari pada kelas eksperimen 2 dengan model pembelajaran talking stick. Data hasil belajar siswa inilah yang akan digunakan untuk mengetahui perbandingan penerapan model pembelajaran snowball throwing dan model pembelajaran talking stick dengan cara menganalisis datanya. Selain hasil belajar siswa juga akan digunakan data hasil analisis kuesioner minat belajar siswa untuk mengetahui perbandingan minat belajar siswa yang menerapkan model pembelajaran snowball throwing dan model pembelajaran talking stick.

\section{Minat Belajar Siswa}

Dari hasil pengolahan data kuesioner minat belajar siswa dari kedua kelas eksperimen, maka diperoleh data seperti pada tabel 2 .

Tabel 2. Hasil Kuisioner Minat Belajar

\begin{tabular}{|c|c|c|c|c|c|}
\hline Variabel & $\mathrm{n}$ & \multicolumn{4}{|c|}{ Skor } \\
\hline Kelas & & Maks & Min & Rata-rata & $\begin{array}{c}\text { Total } \\
\text { Capaian }\end{array}$ \\
\hline $\begin{array}{c}\text { Snowball } \\
\text { Throwing }\end{array}$ & 33 & 199 & 141 & 167,212 & 5518 \\
\hline $\begin{array}{c}\text { Talking } \\
\text { Stick }\end{array}$ & 33 & 185 & 125 & 154,515 & 5099 \\
\hline
\end{tabular}

Dari tabel 2 dapat dilihat bahwa rata-rata skor yang dicapai pada kelas eksperimen 1 yang menerapkan model pembelajaran snowball throwing lebih tinggi daripada kelas eksperimen 2 yang menerapkan model pembelajaran talking stick.

\section{Uji Normalitas}

Uji normalitas bertujuan untuk mengetahui apakah hasil belajar dan minat belajar siswa dari kedua kelas eskperimen berdistribusi normal atau tidak dengan menggunakan program aplikasi SPSS 16 pada taraf signifikansi 0,05. Dengan hipotesis:

Ho: data berasal dari populasi berdistribusi normal

Ha: data tidak berasal dari populasi berdistribusi normal

Pada uji normalitas hasil belajar dan minat belajar siswa ini, jika nilai signifikansi yang diperoleh > 0,05, maka kelas eksperimen berasal dari populasi yang berdistribusi normal, tetapi jika nilai signifikansi yang diperoleh $<0,05$, maka kelas eksperimen berasal dari populasi yang tidak berdistribusi normal [23].

Dari hasil perhitungan dapat diketahui bahwa hasil belajar siswa untuk kedua kelas eksperimen diperoleh nilai signifikansi $>0,05$ yaitu $0,106>0,05$ untuk kelas snowball throwing dan 0,313>0,05 untuk kelas talking 
stick. Sedangkan minat belajar siswa untuk kedua kelas eksperimen diperoleh nilai signifikansi > 0,05 yaitu $0,948>0,05$ untuk kelas snowball throwing dan 0,985 > 0,05 untuk kelas talking stick.

Hal ini menunjukkan bahwa kedua kelas eksperimen baik yang menggunakan model pembelajaran snowball throwing dan model pembelajaran talking stick berdistribusi normal, yang berarti data yang diperoleh memiliki sebaran normal dan bisa mewakili populasi atau Ho diterima.

\section{Uji Homogenitas}

Setelah dilakukan uji normalitas selanjutnya dilakukan uji homogenitas yang bertujuan untuk mengetahui apakah varians data hasil belajar dan minat belajar siswa dari kedua kelas eksperimen yang digunakan tersebut mempunyai varians yang homogen atau tidak, dimana uji homogenitas hasil belajar siswa berdasarkan dari selisih nilai rata-rata postest dan nilai rata-rata pretest dilakukan, sedangkan uji homogenitas minat belajar siswa berdasarkan skor kuesioner yang diperoleh siswa.

Uji homogenitas dihitung melalui uji $\mathrm{F}$ pada taraf signifikansi 0,05 . Kriteria pengujian homogenitasnya adalah jika $\mathrm{F}_{\text {hitung }}<\mathrm{F}_{\text {tabel }}$, maka kedua kelas eksperimen memiliki varians yang homogen, tetapi jika $F_{\text {hitung }}<\mathrm{F}_{\text {tabel }}$, maka kedua kelas eksperimen memiliki varians yang tidak homogen.

Setelah perhitungan diperoleh nilai $\mathrm{F}_{\text {hitung }}<$ $F_{\text {tabel }}(1,183<3,991)$ untuk hasil belajar siswa dan nilai $\mathrm{F}$ hitung $<\mathrm{F}_{\text {tabel }}(1,190<3,991)$ untuk minat belajar siswa, maka data memiliki varians yang homogen. Varians yang homogen memiliki arti bahwa kedua kelas eksperimen memiliki tingkat kemampuan kognitif dan minat belajar yang sama [24]. Selanjutnya, karena kedua kelas eksperimen berdistribusi normal dan memiliki varians yang homogen maka dapat dilakukan pengujian hipotesis dengan melakukan uji t.

\section{Uji Hipotesis}

Uji hipotesis digunakan untuk melihat apakah terdapat perbedaan yang signifikan dari hasil belajar dan minat belajar siswa pada penelitian dengan menerapkan model pembelajaran snowball throwing dan talking stick di SMAN 10 Kota Bengkulu.
Uji hipotesis ini dilakukan melalui uji $\mathrm{t}$ pada taraf signifikan 0,05 dengan menggunakan data perbandingan nilai rata-rata hasil pretest dan postest, rata-rata hasil skor kuesioner, serta varianskedua kelas eksperimen. Dalam uji t ini, jika $\mathrm{t}_{\text {hitung }}>\mathrm{t}$ tabel, maka Ha diterima dan Ho ditolak yang berarti terdapat perbedaan yang siginifikan antara hasilbelajar dan minat belajar kimia siswa dengan menerapkan model pembelajaran snowball throwing dan model pembelajaran talking stick begitu pula sebaliknya.

Dari hasil perhitungan uji hipotesis yangdilakukan dapat diketahui bahwa $t_{\text {hitung }}>$ $\mathrm{t}_{\text {tabel}}$, yaitu 4,734>1,669 untuk hasil belajar dan 3,596 > 1,669 untuk minat belajar, maka dapat disimpulkan bahwa Ho ditolak dan Ha diterima.

Hal ini berarti terdapat perbedaan yang signifikan antara hasil belajar dan minat belajar kimia siswa dengan menerapkan model pembelajaran snowball throwing dan model pembelajaran talking stick.

Hal ini juga sesuai dengan penelitian yang pernah dilakukan yang mengatakan bahwa penggunaan metode pembelajaran kooperatif tipe snowball throwing lebih sesuai daripada metode pembelajaran kooperatif tipe talking stick dalam peningkatan prestasi belajar [25].

Pada dasarnya peningkatan hasil belajar pada model pembelajaran snowball throwing ini juga dipengaruhi oleh adanya pendekatan saintifik, sehingga berpengaruh pada hasil belajar yang diperoleh karena siswa tidak hanya mengikuti langkah-langkah pada model pembelajaran, tetapi juga tahapan pendekatan saintifik mulai dari mengamati, menanya, mengumpulkan data, mengasosiasi, dan mengkomunikasikan [26].

Besarnya pengaruh penerapan model pembelajaran terhadap hasil belajar berdasarkan uji statistik regresi linier sederhana yaitu 1,6\%, sedangkan $98,4 \%$ dipengaruhi oleh banyak faktor eksternal salah satunya yaitu pendekatan saintifik.

\section{Hasil Analisis Kuesioner Minat}

Kuesioner minat belajar siswa ini terdiri dari 41 butir pernyataan yang terbagi menjadi 21 butir pernyataan positif dan 20 butir pernyataan negatif. Setelah seluruh data kuesioner terkumpul selanjutnya menganalisis data tersebut sehingga dapat ditarik suatu kesimpulan.

Analisis kuesioner ini dilakukan dengan menggunakan skor capaian dari setiap responden 
yang kemudian dikonversi dalam bentuk hasil persentase dan juga dikonversikan dalam beberapa kategori. Sehingga dapat diketahui bagaimana minat belajar siswa pada kelas eksperimen 1 dan kelas eksperimen 2 yang masing-masing menerapkan model pembelajaran snowball throwing dan talking stick.

Berdasarkan hasil perhitungan kuesioner tersebut data minat belajar siswa pada kedua kelas eksperimen dapat dilihat pada tabel 3.

Tabel 3. Hasil Analisis Kuisioner Minat

\begin{tabular}{|c|c|c|c|c|c|}
\hline Variabel & $\mathrm{n}$ & \multicolumn{2}{|c|}{ Skor } & $\%$ & Kategori \\
\hline Kelas & & Maks & $\begin{array}{c}\text { Rata- } \\
\text { rata }\end{array}$ & & \\
\hline $\begin{array}{l}\text { Snowball } \\
\text { Throwing }\end{array}$ & 33 & \multirow[t]{2}{*}{205} & 167,212 & 81,567 & $\begin{array}{l}\text { Sangat } \\
\text { Baik }\end{array}$ \\
\hline $\begin{array}{l}\text { Talking } \\
\text { Stick }\end{array}$ & 33 & & $\begin{array}{l}154, \\
515\end{array}$ & 75,373 & Baik \\
\hline
\end{tabular}

Dari tabel 3 dapat dilihat bahwa hasil persentase dari kedua kelas eksperimen berbeda, hal ini berarti minat belajar siswa dengan menerapkan model pembelajaran snowball throwing lebih baik jika dibandingkan dengan minat belajar siswa dengan menerapkan model pembelajaran talking stick.

Hal ini dapat terjadi karena ketertarikkan siswa pada suatu mata pelajaran timbul dari hasil interaksi yang terjadi antarasiswa dengan lingkungannya, hal ini termasuk bagaimana interaksi siswa dengan teman-temannya[27]. Teman sebaya berperan dalam pembentukan minat siswa karena interaksi antar teman sebaya termasuk salah satu faktor yang mempengaruhi pembentukan minat pada siswa [28].

Keterlibatan siswa dalam belajar akan menjadi semakin baik saat mereka berada pada lingkungan yang dipenuhi dengan teman-teman sebaya yang akan selalu mendorong siswa untuk terlibat dalam aktivitas pembelajaran karena keberadaan partner belajar yang baik akan mampu untuk membangkitkan minat belajar siswa [29].

Hal ini sesuai dengan hasil penelitian terdahulu terhadap minat belajar siswa yang menerapkan model pembelajaran snowball throwing yang membuktikan memberikan hasil yang lebih baik daripada minat belajar siswa dengan menerapkan model pembelajaran talking stick dengan adanya pengaruh pendekatan saintifik [30].
Besarnya pengaruh penerapan model pembelajaran terhadap minat belajar berdasarkan uji statistik regres linier sederhana yaitu $0,9 \%$, sedangkan 99,1\% dipengaruhi oleh banyak faktor eksternal salah satunya yaitu pendekatan saintifik.

Dengan demikian, dari hasil dan penjelasan yang telah diuraikan diatas, maka dapat disimpulkan bahwa hasil belajar kimia siswa dan minat belajar kimia siswa yang menerapkan model pembelajaran kooperatif snowball throwing lebih baik dibandingkan dengan model pembelajaran kooperatif talking stick di kelas $\mathrm{X}$ IPA SMA Negeri 10 Kota Bengkulu pada materi tata nama senyawa kimia.

Hal ini diduga karena model snow ball throwing memiliki kelebihan dapat membuat siswa menjadi lebih bersemangat untuk memahami materi dengan bekerjasama secara berkelompok, sehingga lebih banyak terjadi interaksi, kontribusi, dan partisipasi antar siswa didalamnya, artinya terjadi hubungan timbal-balik antar siswa, saling memberikan sumbangan pemikiran, dan ikut aktif dalam kelompok.

Selain itu, pada model pembelajaran snowball throwing ini dapat melatih kesiapan siswa dalam merumuskan pertanyaan dengan bersumber pada materi yang diajarkan [31] serta membuat siswa lebih termotivasi untuk bersaing dan berani mengemukakan pendapatnya karena soal berasal dari pertanyaan yang dibuat oleh temannya sendiri[32].

Namun dalam pelaksanaannya, model pembelajaran snowball throwing ini juga mempunyai kekurangan yaitu menimbulkan sedikit keributan pada saat proses pelemparan bola berisi soal dari satu kelompok ke kelompok lainnya dan masih ada siswa yang belum sepenuhnya memahami materi.

Model pembelajaran talking stick ini juga terbukti dapat meningkatkan hasil belajar siswa walaupun peningkatan hasil belajarnya tidak sebesar model pembelajaran snowball throwing. Adapun kelebihan dari penggunaan model pembelajaran talking stick yaitu dapat melatih keterampilan siswa dalam membaca dan memahami materi pelajaran dengan cepat, mengajak siswa untuk terus siap dalam situasi apapun [33], serta dapat melatih siswa dalam menjawab pertanyaan dari guru dengan cepat, tepat, dan benar[34].

Dalam pelaksanaannya, model pembelajaran talking stick ini mempunyai 
beberapa kelemahan yang terlihat pada saat penelitian diantaranya adalah siswa menjadi tegang dan was-was ketika tongkat diputar sehingga mereka bertanya-tanya apakah bisa menjawab pertanyaan dari guru atau tidak, siswa yang tidak siap tidak bisa menjawab dan menjadi ketakutan akan pertanyaan yang akan diberikan oleh guru, siswa yang terlalu cepat dan tergesagesa dalam memberikan tongkatnya kepada teman lain karena takut jika tongkat tersebut berada ditangan mereka ketika musik berhenti, serta secara emosional siswa belum terlatih untuk berbicara di hadapan guru [35], serta kondisi kelas yang kurang kondusif karena siswa mengikuti alunan musik yang sedang diputar sehingga akan dapat mengganggu proses pembelajaran dikelas lain.

\section{KESIMPULAN}

Berdasarkan hasil penelitian yang telah dilakukan dapat disimpulkan bahwa terdapat perbedaan yang signifikan antara hasil dan minat belajar kimia siswa kelas X IPA SMA Negeri 10 Kota Bengkulu tahun ajaran 2017-2018 yang menggunakan model pembelajaran snowball throwing dan model pembelajaran talking stick pada kurikulum-2013

Hasil belajar kedua kelas menjadi lebih meningkat, hal ini dapat diketahui dari perolehan nilai rata-rata pretest dan postest untuk kelas snowball throwing yaitu 22,879 dan 79,848, perolehan nilai rata-rata pretest dan postest untuk kelas talking stick yaitu 31,818 dan 77,424. Sedangkan minat belajar kimia siswanya untuk kelas snowball throwing memperoleh persentase sebesar 81,567\% dan dapat dikategorikan sangat baik, serta untuk kelas talking stick memperoleh persentase sebesar 75,373 \% dan dapat dikategorikan baik.

\section{SARAN}

Dalam penggunaan kedual model pembelajaran baik snowball throwing maupun talking stick sebaiknya ditambahkan dengan media pembelajaran yang bertujuan untuk lebih membantu siswa lagi dalam memahami materi yang dipelajari selain penggunaan LDPD.

Pada saat proses pelemparan bola kertas yang berisi soal sebaiknya tidak dilakukan secara bersama, tetapi dilakukan secara bergantian pada tiap kelompok, hal ini untuk mengurangi kondisi kelas yang dapat menjadi sedikit ribut saat proses pelemparan berlangsung.

Pada saat pelaksanaan model pembelajaran Talking stick, guru harus pandai-pandai dalam mengatur arah dari tongkat agar dapat merata pada seluruh siswa.

\section{DAFTAR PUSTAKA}

[1] Rati , N.W., Ni Pt. Wiwin Sucidamayanti, Penerapan Model Pembelajaran Kooperatif Tipe Numbered Heads Together Untuk Mrningkatkan Hasil Belajar IPS, International Journal of Elementary Education. 2017, 1 (2) : 115-124.

[2] Nurkholis, Pendidikan Dalam Upaya Memajukan Teknologi, Jurnal Kependidikan, 2013: 1 (1): 24-44.

[3] Rozikin, S., Hermansyah Amir, Salastri Rohiat, Hubungan Minat Belajar Siswa Dengan Prestasi Belajar Siswa Pada Mata Pelajaran Kimia Di SMA Negeri 1 Tebat Karai Dan SMA Negeri 1 Kabupaten Kepahiang, Alotrop, 2018 :2(1): 78-81.

[4] Zein, M., Peran Guru Dalam Pengembangan Pembelajaran, Jurnal Inspiratif Pembelajaran, 2016: 5(2): 274285.

[5] Slameto.2015.Belajar Dan Faktor Yang Mempengaruhi.Jakarta: Rineka Cipta. ISBN:978-979-518-166-8

[6] Fatchurrochman,R., Pengaruh Motivasi Berprestasi Terhadap Kesiapan Belajar, Pelaksanaan Prakerin Dan Pencapian Mata Pelajaran Produktif, INVOTEC, 2011: 7(2):175-188.

[7] Abdullah, R., Pembelajaran Dalam Perspektif Kreativitas Guru Dalam Pemanfaatan Media Pembelajaran, Lantanida Journal, 2016: 4 (1): 35-49.

[8] Muthoharoh, N, B, Pengaruh Model Pembelajaran Kooperatif "Think Pair Share (TPS)" Terhadap Hasil Belajar Bahasa Inggris , Jurnal SAP, 2017 : 2(1): 33-42.

[9] Lestari, I.A, Hermansyah Amir, Salastri Rohiat, Hubungan Persepsi Siswa Kelas X MIPA Di SMA Negeri Sekota Bengkulu Tahun Ajaran 2016/2017 Tentang Variasi Gaya Mengajar Guru Dengan Hasil Belajar Kimia, Alotrop, 2017:1(2): 113-116. 
[10] Ginting, S.M., Hermansyah Amir., Penerapan Model Pembelajaran Somatis Auditori Visual dan Intelektual (SAVI) Berbantuan Media Komputer untuk Meningkatkan Kualitas Pembelajaran Kimia Fisika II, EXACTA , 2012: 10 (1), 98-105.

[11] Amir,H., Korelasi Pengaruh Faktor Efikasi Diri Dan Manajemen Diri Terhadap Motivasi Berprestasi Pada Mahasiswa Pendidikan Kimia Universitas Bengkulu, Manajer Pendidikan, 2016: 10(4): 336-342.

[12] Razak , M., Yusminah Hala, A. Mushawwir Taiyeb., Efektifitas Pendekatan Saintifik Terhadap Keterampilan Proses Sains dan Hasil Belajar Kognitif Biologi Peserta Didik Kelas XII IPA SMA Negeri 4 Watampone, Jurnal Sainsmat, 2016: 5(1): 58-73.

[13] Machin, A. 2014. Implementasi Pendekatan Saintifik, Penanaman Karakter Dan Konservasi Pada Pembelajaran Materi Pertumbuhan.Jurnal Pendidikan IPA Indonesia.2014:3(1):28-35

[14] Lestari, D.A., Pendekatan Saintifik Dalam Pembelajaran Tematik Untuk meningkatkan ketrampilan bertanya siswa, Widyagogik, 2015: 3 (1): 62-79.

[15] Handayani,T., Mujasam, Sri Wahyu Widyaningsih, Irfan Yusuf, Penerapan Model Pembelajaran Kooperatif Tipe Snowball Throwing Terhadap Hasil Belajar Peserta Didik , Jurnal Curricula , 2017: 2(1): 47-58.

[16] Meirza Nanda Faradita, Pengaruh Metode Pembelajaran Type Talking Stick Terhadap Hasil Belajar IPA pada Siswa Kelas 4 Sekolah Dasar, Jurnal Bidang Pendidikan Dasar, 2018 : 2(1A) : 47-58.

[17] Sari, Y.A, Amrul Bahar, Salastri Rohiat., Studi Perbandingan Pembelajaran Kooperatif Menggunakan Media Kartu Pintar Dan Kartu Kemudi Pintar, Alotrop .2017: 1(1): 44-48

[18] Nugroho, A.T.R., Sukiswo Supeni Edie, Upaya Peningkatan Minat Dan Hasil Belajar Siswa Melalui Metode Learning Start With A Question Pada Siswa Kelas XI SMAN 1 Kendal, Unnes Physics Education Journal. (UPEJ): 2015 : 4 (3) : 10-16.
[19] Clorawati, A.R., Salastri Rohiat, Hermansyah Amir. Implementasi Kurikulum 2013 Bagi Guru Kimia di SMA Negeri Sekota Bengkulu. Alotrop. 2017 :1(2): 132-135.

[20] Trinova, Z., Hakikat Belajar Dan Bermain Menyenangkan Bagi Peserta Didik , Jurnal Al-Ta'lim, 2012: 1(3): 209-215

[21] Widi, R., Uji Validitas Dan Reliabilitas Dalam Penelitian Epidemiologi Kedokteran Gigi, Stomatognatic (J.K.G. Unej), 2011: 8 (1): 27-34

[22] Nalendra, A.R.A., Sariwaty Agus Suhaila, Pengaruh Implementasi Kebijakan dan Budaya Organisasi Terhadap Kualitas Pelayanan Publik, Widya Cipta , 2018: 2(1): 141-148.

[23] Nadun, Pengaruh Minat Belajar Siswa Terhadap Hasil Belajar Trigonometri, JKPM (Jurnal Kajian Pendidikan Matematika) , 2017: 3(1): 67-76.

[24] Harjono, A.C., Sarwi, Sulhadi, Penerapan Model Active Learning Berbasis Kooperatif Untuk Meningkatkan Pemahaman Konsep Dan Kinerja Siswa , Unnes Physics Education Journal , 2013: 2 (3): 1-7.

[25] Antari, N.M.D., Ketut Agustini, Dewa Gede Hendra Divayana, Studi Komparatif Model Pembelajaran Talking Stick Dan Snowball Throwing Terhadap Hasil Belajar Teknologi Informasi Dan Komunikasi (TIK) Siswa Kelas XI SMA Negeri 1 Seririt Tahun Ajaran 2015/2016, Jurnal Pendidikan Teknologi dan Kejuruan, 2016: 13(2): 127-136.

[26] Ardaya, D.A., Penerapan Pendekatan Saintifik Untuk Meningkatkan Pemahaman Konsep Materi IPA Siswa Sekolah Dasar, Jurnal Pendidikan Guru Sekolah Dasar, 2016: 1 (1): 72-83.

[27] Simbolon , N., Faktor-faktor Yang Mempengaruhi Minat Belajar Peserta Didik , Elementary School Journal PGSD FIP Unimed , 2013: 1(2): 14-19

[28] Fitriani, Abdul Karim, Pengaruh Kelompok Teman Sebaya Dan Relasi Siswa Dalam Keluarga Terhadap Hasil Belajar IPS Siswa Di SMPN 4 Rumbio Jaya, PeKA: Jurnal Pendidikan Ekonomi Akuntansi FKIP UIR, 2017: 5 (1): 96-104. 
[29] Humam, A.F., M. Nur Rokhman, Upaya Meningkatkan Minat Belajar Siswa Melalui Penerapan Metode SQ3R (Survey , Question , Read, Recite , Review ) Dalam Pembelajaran Sejarah Indonesia Kelas X MIPA 3 SMA $N$ Klaten Jawa Tengah Tahun Ajaran 2017/2018, Jurnal Pendidikan Sejarah, 2018: 5 (4): 349-359.

[30] Susilawati. , Perbandingan Hasil Belajar Siswa Menggunakan Model Pembelajaran Tipe Talking Stick dan Snowball Throwing pada Materi Redoks Kelas X MA Univa Medan CHEDS: Journal of Chemistry, Education, and Science, 2018: 2(1): 56-67

[31] Sartono, L,N., Pengaruh Metode Snow Ball Throwing Terhadap Hasil Belajar Matematika Siswa SD, ELSE (Elementary School Education Journal), 2017: 1(1): 7784.

[32] Sari, R.D., Satrijo Budi Wibowo, Juli Murwani, Perbedaan Prestasi Belajar Akuntansi Dengan Menggunakan Metode Pembelajaran Kooperatif Tipe Snowball Throwing Dan Talking Stick Pada Siswa Kelas XII IPS Di SMA Negeri 1 Wungu, ASSETS : Jurnal Akuntansi dan Pendidikan, 2015: 4 (1): 73-81.
[33] Novida,I., Penerapan Model Talking Stick Untuk Meningkatkan Hasil Belajar IPS Pada Materi Jasa Dan Peranan Tokoh Pejuang Dalam Memproklamasikan Kemerdekaan Indonesia Pada Siswa Kelas V SD Negeri 20 Meulaboh Kabupaten Aceh Barat , Jurnal Bina Gogik, 2016: 3 (1): 114.

[34] Norpah, Peningkatan Keterampilan Bertanya Siswa Kelas VIII SMPN 5 Muara Uya Melalui Model Pembelajaran Talking Stick, SOCIUS: Jurnal Pendidikan dan Pembelajaran Ilmu Pengetahuan Sosial, 2017: 6 (2): 269-282.

[35] Boinah, Upaya Meningkatkan Hasil Belajar Pendidikan Kewarganegaraan Melalui Model Pembelajaran Talking Stick, Jurnal Civics, 2017: 14 (1): 1-9.

Penulisan Sitasi Artikel ini adalah Saputri,R.J., Sumpono,Rina Elvia., Perbandingan Hasil Dan Minat Belajar Kimia Siswa Kelas X IPA Menggunakan Model Pembelajaran Kooperatif Snowball Throwing Dan Talking Stick Pada Kurikulum 2013 Di SMAN 10 Kota Bengkulu, Alotrop, 2018: 2(2): 166-174. 